\title{
The cytopathic Effects of Trichomonas vaginalis on Fibroblast Cell Culture Alone and with C. albicans and E. coli
}

\author{
Klinik Örneklerden İzole Edilen Trichomonas vaginalis in Tek veya Candida ve E. coli ile \\ Birlikte L929 Fare Fibroblast Hücre Kültür Serileri Üzerine Sitopatik Etkisi
}

\author{
Semra Özçelik', Zeynep Sümer², Serpil Değerli', Erdoğan Malatyalı1, Haldun Sümer³ \\ 'Department of Parasitology, Faculty of Medicine, Cumhuriyet University, Sivas, Turkey \\ ${ }^{2}$ Department of Microbiology, Faculty of Medicine, Cumhuriyet University, Sivas, Turkey \\ ${ }^{3}$ Department of Public Health, Faculty of Medicine, Cumhuriyet University, Sivas, Turkey
}

\begin{abstract}
Objective: In this study, the cytopathic effects of Trichomonas vaginalis were investigated in L929 mouse fibroblast cell cultures (FCC) under different conditions: only parasite, or coexistence with Candida albicans and Escherichia coli.

Methods: The parasite was isolated from a symptomatic patient and cultured in Cysteine-Peptone-Liver infusion Maltose medium (CPLM). C. albicans strain 10235 and E. coli strain 25922 were used in the experiments. Five groups were created and inoculated on FCC. The groups were as follows; only T. vaginalis, C. albicans, E. coli, T. vaginalis+C. albicans and T. vaginalis+E. coli. The plates were incubated for 24 hours and cell viability was examined under an inverted microscope. Each experiment was repeated 11 times.

Results: The fibroblast death rate was $19.1 \%, 21 \%, 40.9 \%, 96.5 \%$ and $89.6 \%$ in the five groups, respectively.

Conclusion: All fibroblasts were alive in the control group. T. vaginalis showed almost $100 \%$ cytopathic effects on FCC with C. albicans and parasites were very motile in this coexistence. (Turkiye Parazitol Derg 2012; 36: 193-7)
\end{abstract}

Key Words: Trichomonas vaginalis, fibroblast cell culture, Candida albicans, Escherichia coli, cytopathic effect

Received: 15.02 .2012

Accepted: 06.08.2012

\section{ÖZET}

Amaç: Çalışmada, T. vaginalis'in fibroblast hücre kültürlerinde hem tek başına hem de E. coli ve Candida ile oluşturabilecekleri sitopatik etkinin araştırılması amaçlanmıştır.

Yöntemler: Bu amaçla, L929 fare fibroblast hücre serisi ve T. vaginalis'in kültüründe ise CPLM besiyeri kullanılmıştır. Deneylerde semptomatik klinik örneklerden izole edilen yerel bir T. vaginalis suşu, Candida 10235 suşu ve E. coli 25922 suşu ile çalışılmıştır. Deneysel çalışmada; altı grup oluşturulmuş ve fibroblast kültürü üzerine inoküle edilmişlerdir. Bu gruplar; 1. T. vaginalis, 2. Candida, 3. E.coli, 4. T. vaginalis+Candida, 5. T. vaginalis $+E$. coli ve 6. Kontrol (fibroblast kültürü)'dür. Plaklar $\% 5 \mathrm{CO}_{2}^{\prime}$ li etüvde $37^{\circ} \mathrm{C}^{\prime}$ de 24 saat inkübe edildikten sonra inverted mikroskop altında gözlenerek canlılık sayımları yapılmıştır. Çalışmada grupların herbiri 11 kez çalışımıştır. Kruskall-Wallis, Mann-Whitney U testi kullanılarak sonuçlar değerlendirilmiştir.

Bulgular: Kontrol grubundaki L929 fare fibroblast hücrelerinin tamamı canlı iken, 1. grupta bulunan yalnız T. vaginalis'in inoküle edildiği hücre kültürlerinde fibroblastların \%19.09'unun, 2. grupta bulunan yalnız Candida'nın \%21.00'inin, 3. grupta E. coli'nin tek başına olduğu kültürlerde \%40.91'inin, 4. grupta T. vaginalis ve Candida'nın birlikte ekildiği hücre kültüründe \%96.55'inin, 5. grupta T. vaginalis ve E. coli'nin birlikte inoküle edildiği godelerde ise hücrelerin \%89.64'ünün öldüğü saptanmıştır.

Sonuç: T. vaginalis'in fibroblast hücre kültüründe patojen etkisi özellikle Candida varlığında çok daha belirgin olmaktadır. (Turkiye Parazitol Derg 2012; 36: 193-7)

Anahtar Sözcükler: Trichomonas vaginalis, fibroblast cell culture, Candida albicans, Escherichia coli, sitopatik etki Geliş Tarihi: 15.02.2012 Kabul Tarihi: 06.08.2012

Address for Correspondence / Yazışma Adresi: Dr. Semra Özçelik, Department of Parasitology, Faculty of Medicine, Cumhuriyet University, Sivas, Turkey Phone: +90 5326231917 Fax: +90 3462191155 E-mail: ozceliksemra@yahoo.com doi:10.5152/tpd.2012.47 


\section{INTRODUCTION}

Trichomoniosis is the most common non-viral sexually-transmitted disease around the world. Each year, approximately 170 million people are infected with the parasite (1). The most prominent complaint in trichomoniosis is vaginal discharge. The patients mostly complain of burning and itching. Upon examination of vaginal mucosa with a speculum, common hyperaemic, bright red lesions can be observed. The most common urinary symptom is dysuria; cystitis can also be seen in very few cases (2). Cervical carcinoma has been reported to show a relationship with $T$. vaginalis $(3,4)$. The infection is usually asymptomatic in men. T. vaginalis may play an important role as a cofactor in the transmission of the HIV virus. In some studies in Africa, levels of HIV positivity in T. vaginalis positive individuals were found to be more than two-fold (5). To touch on in vitro studies, in cultured mammalian cells T. vaginalis showed cytopathic effects (6-8). Parasites kill the target cells with only direct contact (9). Four different trichomonas surface proteins were identified adhering to cells easily (10). Also, T. vaginalis cell separation factor (celldetaching-factor, CDF), mammalian cell culture cells leads to leave. A correlation was found between the severity of the infection and CDF in the pathogenesis of T. vaginalis (7). For many years, T. vaginalis was accepted as an apathogenic microorganism; however, both in vivo and in vitro studies have revealed that it is actually pathogenic (10-17). T. vaginalis was first grown by cell culture in the 1940s; Houge investigated the effect of the parasite on fibroblast cells in 1943. In those studies, it was attempted to determine the parasite's effect on cells, and whether there are any mechanical effects, toxins or enzymatic reactions (16). Heath worked on the effect of pathogenesis of the parasite on a single layer of vaginal epithelial cells in 1981 and found that approximately $10 \%$ of cells died in cultures (15).

However, there has been no study regarding the damage caused by $T$. vaginalis on cell lines with $C$. albicans. Therefore, this study investigated whether T. vaginalis, both alone and with $E$. coli and C. albicans, can play a role in the cytopathic effects on FCC.

\section{METHODS}

\section{Test Microorganisms}

T. vaginalis was isolated from a female patient with clinical symptoms of urogenital disease and cultured in CPLM. C. albicans 10231 and E. coli 25922 strains were used in the assays.

\section{Cultivation of $T$. vaginalis}

The medium was renewed every three or four days to keep the parasites alive. Before inoculation, the medium was heated at $37^{\circ} \mathrm{C}$ for a few minutes and $1 \mathrm{~mL}$ of inoculum was transferred to fresh medium. 20\% inactivated human serum (heat inactivated at $56^{\circ} \mathrm{C}$ for $30 \mathrm{~min}$ and cooled), Penicillin G, streptomycin and Triflucan was added to each tube.

\section{Fibroblast Cell Culture}

The L929 mouse fibroblast cell line was used in this study. FCC passages were continued in order to ensure its sustainability and viability. Cells in the flasks were washed with PBS, and then rinsed with a trypsin/EDTA solution (0.05\% trypsin $+0.02 \%$ EDTA). Trypsin was aspirated from flasks. The flasks were incubated $37^{\circ} \mathrm{C}$ in an incubator for $5 \mathrm{~min}$ and then cells were sepa- rated from the surface of flasks. The cell suspension was created by adding DMEM. The prepared cell suspension was divided into two flasks and was passaged. Cell proliferation was viewed in flasks. This process was repeated and continuity of cell culture was achieved.

\section{Experimental Design}

Six groups were formed in the experiments and were inoculated on FCC. The groups created were as follows:

1. T. vaginalis $\left(1.2 \times 10^{6}\right.$ parasite $\left./ \mathrm{mL}\right)$

2. C. albicans

3. E. coli

4. T. vaginalis + C. albicans

5. T. vaginalis + E. coli

6. Control FCC (no microorganism inoculation)

In the study, the cells collected from the L929 fibroblast cell series were placed in 24-well cell culture plates. The monolayer of fibroblast cells in the wells occurred within 24 hours. Solutions were inoculated in the wells: the first group contained $100 \mu \mathrm{L}$ of T. vaginalis, the second group had $100 \mu \mathrm{L}$ of C. albicans, and the third group contained $100 \mu \mathrm{L}$ of E. coli. In the fourth group, both T. vaginalis and C. albicans (100 $\mu \mathrm{L}$ each) were inoculated, and the fifth group included both T. vaginalis and E. coli $(100 \mu \mathrm{L})$. Cells in the last group formed the control group. Plates were incubated for 24 hours at $5 \% \mathrm{CO}_{2}$ and $37^{\circ} \mathrm{C}$. Then, cells were examined under an inverted microscope (Eclipse TS 100, Nikon, Tokyo, Japan) and viability counts were performed with $0.01 \%$ neutral red. Each group was studied 11 times.

\section{Statistical Analysis}

SPSS 15.0 for Windows was used to analyse the statistical parameters. Significance between two means in an independent group was assessed by using Mann-Whitney $U$ and Kruskal Wallis tests. The data was presented as mean \pm standard deviations and the $p$ value was set at 0.01 .

\section{RESULTS}

After incubation for $24 \mathrm{~h}$, all of the control cells were attached and formed a normal monolayer (Figure 1A). In the inoculated $E$. coli group, a level of $40.91 \pm 8.03 \%$ was obtained for cell death (Figure 1B). At that time, the effects of T. vaginalis in the groups were clearly visible in $\mathbf{L 9 2 9}$ fibroblast cell cultures. In this first group of inoculated $T$. vaginalis, cell death was determined to be $19.09 \pm 4.74 \%$ (Figure 1C). The inoculated parasites were seen to attach to the monolayer and divide, producing a visible focal lesion. While the lesion was gradually expanded, the monolayer was destroyed and parasites became free-swimming.

When inoculated with $C$. albicans and T. vaginalis, there was almost no monolayer of fibroblasts and all cells were round. A large amount of $T$. vaginalis was observed and $96.55 \pm 2.91 \%$ fibroblast cells were counted as dead (Figure 1D). When T. vaginalis and $E$. coli were inoculated together in fibroblast cells, the cells left the base and had a round appearance; $89.64 \pm 4.38 \%$ of fibroblasts were dead (Figure 1E). In the group containing only C. albicans, cell death was determined to be $21.00 \pm 4.72 \%$ (Figure 1F). The percentage values of dead cells are presented in Table 1. 

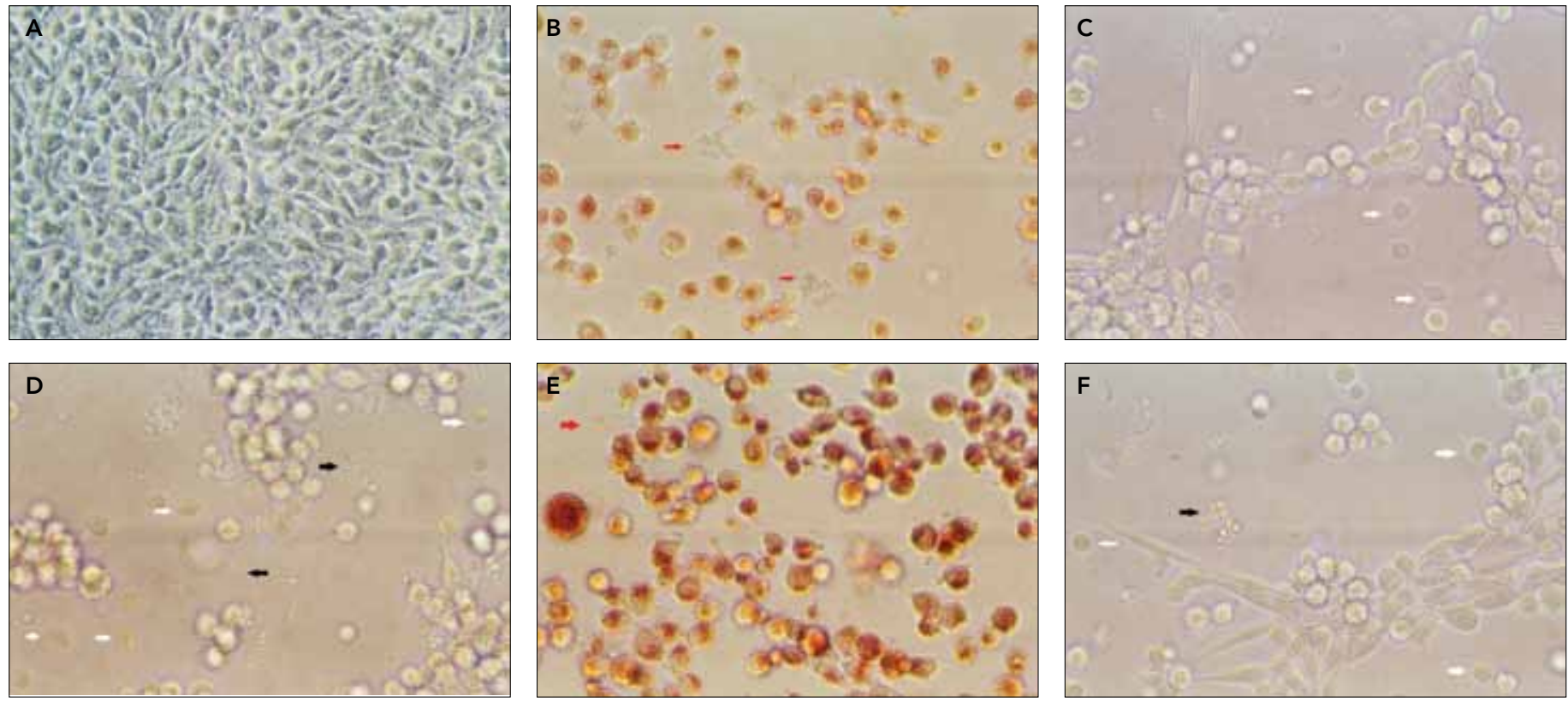

Figure 1. The changes in FCC under different conditions. A) Control-fibroblasts, B) E. coli and fibroblasts, C) T. vaginalis+fibroblasts, D) T. vaginalis+C. albicans+fibroblasts, E) T. vaginalis+E. coli+fibroblasts, F) C. albicans+fibroblasts (white arrows: T. vaginalis, black arrows: C. albicans, red arrows: E. coli)

Table 1. Cytopathic effects of infectious agents on fibroblast cells

\begin{tabular}{|l|c|c|}
\hline Organisms & $\begin{array}{c}\text { \% Live cells } \\
(\mathbf{n}=\mathbf{1 1})\end{array}$ & $\begin{array}{c}\% \text { Dead cells } \\
(\mathbf{n}=\mathbf{1 1})\end{array}$ \\
\hline T. vaginalis & $79.09 \pm 5.15$ & $19.09 \pm 4.74$ \\
\hline C. albicans & $78.91 \pm 4.78$ & $21.00 \pm 4.73$ \\
\hline E. coli & $59.09 \pm 8.03$ & $40.91 \pm 8.03$ \\
\hline T. vaginalis+C. albicans & $3.45 \pm 2.91$ & $96.55 \pm 2.91$ \\
\hline T. vaginalis+E. coli & $9.45 \pm 3.61$ & $89.64 \pm 4.38$ \\
\hline Control & $99.18 \pm 1.25$ & $0.82 \pm 1.25$ \\
\hline
\end{tabular}

A significant difference between live and dead cell groups was determined by Kruskal-Wallis analysis of variance. The MannWhitney $U$ test was used to determine which groups caused the difference. According to this test, while there was no significant difference between the first and second groups ( $p>0.01)$, significant differences were determined between all of the other groups $(p<0.01)$. T. vaginalis and $C$. albicans showed a similar effect on the fibroblast cells; however, the two organisms together were found to make the cytopathic effect about $100 \%$.

\section{DISCUSSION}

Trichomoniosis is one of the most important forms of protozoan parasitosis that is transmitted by sexual intercourse. Depending upon the social conditions, the methods used in diagnosis and the sexual habits of people, its prevalence varies from one country to another. Donne first described the parasite; the question of its pathogenicity has been subject to some degree of controversy. T. vaginalis causes vaginitis in women and urethritis and balanitis in men. During trichomoniosis, significant changes may be observed in the epithelial cell layers of the vagina (2). After Houge's observation that CPE was associated with T. vaginalis in embryonic human and chicken tissue explants, it was estimated that tissue cultures might become useful tools for the demonstration and identification of at least some aspects of the virulence of the organism (16).

To date, virulence factors such as adhesion molecules, proteolysis, haemolysis, cell separation factors and cytotoxicity factors were determined $(6,17-28)$. Adhesion of $T$. vaginalis to the vaginal epithelial cells was found to be effective. Parasite cell surface proteins and glycoproteins provide the host-cell adhesion. To date, four adhesion molecules have been identified (AP65, AP51, AP33 and AP23) (29). In the adhesion process of parasites, the target protein is laminin (28). Parasite surface carbohydrates, such as lectin-binding D-lactose and $\mathrm{N}$-acetyl-D-glucosamine, also have important roles in virulence (30). Parasites are unable to synthesise lipids, so lipids are obtained from erythrocytes. Parasites can haemolyse erythrocytes via cysteine proteases; the effect of this activity in virulence has also been reported (21). Krieger et al. (31), who correlated beta-haemolytic activity by $T$. vaginalis with the symptoms of the patient and with the mouse assay, found that the pathogenic strains had higher haemolytic activity. The parasite has a maximum cysteine protease (23 pieces) $(13,32)$, which reduces immunoglobulin levels in the vagina (27). In vitro studies showed that the cell separation factor decreases in the presence of beta-oestradiol. The cell separation factor is capable of separation without killing the host epithelial cells. This effect was also observed in the present study. Cells separating from the monolayer fibroblast series took the vital dyes, but they became round and small. Other molecules that play a role in the pathogenesis of the parasite show a pore forming molecule perforin-like domain (9). In addition, some of T. vaginalis strains were a virus carried by double-stranded and that the virus was found in the majority of clinical isolates. This virus is thought to play a role in the pathogenesis of the parasite (33).

The cytopathic effects of $T$. vaginalis, both alone and with C. albicans and E. coli, on fibroblast cell culture series were stud- 
ied, and the striking findings of this study were presented. In some earlier studies, the effect of $T$. vaginalis on the cell series was found to be $10 \%(15)$; in our study, this rate was higher $(20 \%)$. This effect increased when C. albicans or E. coli was co-incubated with the parasite; in particular, C. albicans revealed more disruption of FCC, which was almost $100 \%$. Additionally, the trophozoites were very active and motile in this situation. The findings showed that mixed vaginal infections due to $T$. vaginalis and $C$. albicans may result in more complicated clinical symptoms and require a different treatment. Candidiasis is reported as the most common cause of vaginitis in Europe and the second most common cause of vaginitis in the United States (34). According to the World Health Organization (WHO), the worldwide prevalence of trichomoniosis is 174 million and accounts for $10 \%$ to $25 \%$ of vaginal infections (35). The prevalence of trichomoniasis is reported to be approximately 5\% in Turkey (36, 37). These two common infections are found together in many cases, which implies the importance of the present study. Alderete and Pearlman reported an extensive disruption in different monolayers (human urogenital and vagina, human epithelial, normal baboon testicular, and monkey kidney cells) with exposure to $T$. vaginalis (12). The explanation of the cellular disruption in cell monolayers is the key point for understanding the pathogenesis of the parasite. For instance, the presence of $\mathrm{Zn}^{2+}$ downregulates the transcriptional levels of a protein and has a negative effect on trichomonal cytotoxicity, while lipophosphoglycan mutants of $T$. vaginalis shows reduced adherence and cytotoxicity to human ectocervical cells $(38,39)$. Another factor that can affect the cytotoxicity is the source of the parasite; fresh isolates were more cytotoxic and can easily attach to cell layers than laboratory strains that have been cultivated for a long time in axenic cultures (40). In the study, the T. vaginalis strain was isolated from a symptomatic clinical case and freshly used, so the cytopathic effect was not decreased due to long-term cultivation.

\section{CONCLUSION}

The other microorganisms in the vagina may affect the cytotoxic potential of T. vaginalis; in particular, the presence of C. albicans may increase the disruption of epithelial cell layers.

\section{Conflict of Interest}

No conflict of interest was declared by the authors.

\section{REFERENCES}

1. Saygı G. Trichomonas vaginalis in Turkey-a review. Wiadomosci Parazytologiczne 2001; 47: 3-7.

2. Saygı G. Paraziter hastalıklar ve parazitler. Es Form Ofset Ltd.Şti. s:80, Sivas. 2009.

3. Gram IT, Macaluso M, Churchill J, Stalsberg H. Trichomonas vaginalis (TV) and human papillomavirus (HPV) infection and the incidence of cervical intraepithelial neoplasia (CIN) grade III. Cancer Causes Control 1992; 3: 231-6. [CrossRef]

4. Kharsany AB, Hoosen AA, Moodley J, Bagaratee J, Gouws E. The association between sexually transmitted pathogens and cervical intra-epithelial neoplasia in a developing community. Genitourin Med 1993; 69: 357-60

5. Sorvillo F, Smith L, Kerndt P, Ash L. Trichomonas vaginalis, HIV and African-Americans. Emerg Infect Dis 2001; 7: 927-32. [CrossRef]

6. Arroyo R, Alderete JF. Trichomonas vaginalis surface proteinase activity is necessary for parasite adherence to epithelial cells. Infect Immun 1989; 57: 2991-7.
7. Garber GE, Lemchuk-Favel LT, Bowie WR. Isolation of a cell-detaching factor of Trichomonas vaginalis. J Clin Microbiol 1989; 27: 154853.

8. Silva-Filho FC, de Souza W, Lopes JD. Presence of laminin binding proteins in trichomonads and their role in adhesion. Proc Natl Acad Sci 1989; 85: 8042-6. [CrossRef]

9. Fiori PL, Rappelli P, Addis MF, Mannu F, Cappuccinelli P. Contactdependent disruption of the host cell membrane skeleton induced by Trichomonas vaginalis. Infect Immun 1997; 65: 5142-8.

10. Alderete JF, Garza GE. Specific nature of Trichomonas vaginalis parasitism of host cell surfaces. Infect Immun 1985; 50: 701-8.

11. Alderete JF, Newton E, Dennis C, Neale KA. Antibody in sera of patient infected with Trichomonas vaginalis is to trichomonad proteinases. Genitourin Med 1991; 67: 331-4.

12. Alderete JF, Pearlman E. Pathogenic Trichomonas vaginalis cytotoxicity to cell culture monolayers. Br J Vener Dis 1984; 60: 99-105.

13. Alvarez-Sánchez ME, Avila-González L, Becerril-García C, FattelFacenda LV, Ortega-López J, Arroyo R. A novel cysteine proteinase (CP65) of Trichomonas vaginalis involved in cytotoxicity. Microb Pathog 2000; 28: 193-202. [CrossRef]

14. Gilbert RO, Elia G, Beach DH, Klaessig S, Singh BN. Cytopathogenic effect of Trichomonas vaginalis on human vaginal epithelial cells cultured in vitro. Infect Immun 2000; 68: 4200-6. [CrossRef]

15. Heath JP. Behaviour and pathogenicity of Trichomonas vaginalis in epithelial cell cultures: a study by light and scanning electron microscopy. Br J Vener Dis 1981; 57: 106-17.

16. Houge MJ. The effect of Trichomonas vaginalis on tissue culture cells. Am J Hyg 1943; 37: 142.

17. Singh BN, Elia G, Gilbert RO. Cytotoxic effects of Trichomonas vaginalis on human vaginal epithelial cells. Abstr J Soc Gynecol Investig 1999; 6: 447.

18. Arroyo R, Alderete JF. Two Trichomonas vaginalis surface proteinases bind to host epithelial cells and are related to levels of cytoadherence and cytotoxicity. Arch Med Res 1995; 26: 279-85.

19. Burgess DE, Knoblock T, Daugherty T, Robertson NP. Cytotoxic and hemolytic effects of Tritrichomonas foetus on mammalian cells. Infect Immun 1990; 58: 3627-32.

20. Coombs GH, North MJ. An analysis of the proteinases of Trichomonas vaginalis by acrylamide gel electrophoresis. Parasitology 1983; 86: 1-6. [CrossRef]

21. Dailey DC, Chang T, Alderete JF. Characterisation of a hemolysin of proteinases of the parasitic protozoan Trichomonas vaginalis. Parasitology 1990; 101: 171-7. [CrossRef]

22. JulianoC, Monaco G, Bandiera P, Tedde G, Cappuccinelli P. Action of anticytoskeletal compounds on in vitro cytopathic effect, phagocytosis, and adhesiveness of Trichomonas vaginalis. Genitourin Med 1987; 63: 256-63

23. Draper D, Donohoe W, Mortimeer L, Heine RP. Cystein proteiases of Trichomonas vaginalis degrade secretary leucocyte protease inhibitor. J Infect Dis 1998; 178: 815-9. [CrossRef]

24. Krieger JN, Ravdin JI, Rein MF. Contact-dependent cytopathogenic mechanisms of Trichomonas vaginalis. Infect Immun 1985; 50: 77886.

25. Neale KA, Alderete JF. Analysis of the proteinases of representative Trichomonas vaginalis isolates. Infect Immun 1990; 58: 157-62.

26. Pindak FF, Mora de Pindak M, Gardner WA Jr. Contact-independent cytotoxicity of Trichomonas vaginalis. Genitourin Med 1993; 69: 35-40.

27. Provenzano D, Alderete JF. Analysis of human immunoglobulindegrading cysteine proteinases of Trichomonas vaginalis. Infect Immun 1995; 63: 3388-95.

28. Silva-Filho FC, Ortega-Lo'pez J, Arroyo R. YIGSR is the preferential laminin-1 residing adhesion sequence for Trichomonas vaginalis. Exp Parasitol 1998; 88: 240-2. [CrossRef]

29. Alderete JF, O'Brien JL, Arroyo R, Engbring JA, Musatovova O, Lopez $\mathrm{O}$, et al. Cloning and molecular characterization of two genes 
encoding adhesion proteins involved in Trichomonas vaginalis cytoadherence. Mol Microbiol 1995; 17: 69-83. [CrossRef]

30. Warton A, Honigberg BM. Analysis of surface saccharides in Trichomonas vaginalis strains with various pathogenicity levels by fluorescein-conjugated plant lectins. Z Parasitenkd 1983; 69: 149-59. [CrossRef]

31. Krieger JN, Poisson MA, Rein MF. Beta-hemolytic activity of Trichomonas vaginalis correlates with virulence. Infect Immun 1983; 41: 1291-5.

32. Schwebke JR, Burgess D. Trichomoniasis. Clin Microbiol Rev 2004; 17: 794-803. [CrossRef]

33. Wang A, Wang CC. The double-stranded RNA in Trichomonas vaginalis may originate from virus-like particles. Proc Natl Acad Sci USA 1986; 83: 7956-60. [CrossRef]

34. Eschenbach DA, Hillier SL. Advances in diagnostic testing for vaginitis and cervicitis. J Reprod Med 1989; 34: 555-64.

35. World Health Organization. Global Prevalence and incidence of selected curable sexuallytransmittedinfections.2001.WHO/HIV_ AIDS/2001.02WHO/CDS/CSR/EDC/2001.10.Availableat http:// www.emro.who.int/asd/backgrounddocuments/uae03/surv/ stdoverview.pdf.

36. Östan I, Sözen U, Limoncu ME, Kilimcioğlu AA, Özbilgin A. Manisa'da vaginal akıntılı kadınlarda Trichomonas vaginalis sıkığı. Türkiye Parazitol Derg 2005; 29: 7-9.

37. Akarsu GA. Nonspesifik vaginal akıntı şikayeti olan poliklinik hastalarında Trichomonas vaginalis araştıılması. Türkiye Parazitol Derg 2006; 30: 19-21.

38. Bastida-Corcuera FD,Okumura CY, Colocoussi A, Johnson PJ. Trichomonas vaginalis lipophosphoglycan mutants have reduced adherence and cytotoxicity to human ectocervical cells. Eukaryotic Cell 2005; 4: 1951-8. [CrossRef]

39. Carrillo LIV, Granados LIQ, Arroyo R, Hernández GM, Robles AG, Gamez BIC, et al. The effect of $\mathrm{Zn} 2+$ on prostatic cell cytotoxicity caused by Trichomonas vaginalis. Journal of Integrated OMICS 2011; 1: 198-210.

40. Rasmussen SE, Nielsen MH, Lind I, Rhodes JM. Morphological studies of the cytotoxicity of Trichomonas vaginalis to normal human vaginal epithelial cells in vitro. Genitourin Med 1986; 62: 240-6. 